\title{
TO JOIN EFFORTS IN THE FACE OF COMMON CHALLENGES
}

The political changes in Bulgaria at the end of the 1980s marked the beginning of deep and comprehensive reforms in Bulgarian society. They had a tangible impact on science, and in particular on sociology. New opportunities opened up, but also serious challenges were faced.

Sociology expanded its position in the training of higher education professionals and began to be taught in more higher education institutions. Numerous sociological agencies were established, which focused on public opinion polls on a wide range of topics and accumulated a large amount of empirical material that could be used for theoretical interpretations.

After Bulgaria opened up to the world, favourable conditions were created for the integration of Bulgarian sociology into the leading trends. Bulgarian scientists permanently found its place in the European Research Area. For two decades now, Bulgarian sociologists have been working on Framework and other programs of the European Commission and other international institutions and organizations.

At the same time, however, Bulgarian sociology suffered a lot of damage and difficulties occurred. Research units with traditions and indisputable achievements were closed down or severely downsized. Due to the reduced funding, academic sociology faced serious challenges. The need to seek funding from external contractors indirectly affected the choice of research topics. It also affected the methods used. But the explanation of the country's ongoing complex and contradictory transformation processes, of the serious problems and contradictions that have arisen, became the most serious challenge (Genov, 1998, p. 87). Despite all difficulties, Bulgarian sociologists have achieved remarkable results in the study and explanation of the new social realities, proposed and propose ways to optimize social development.

Collaboration between sociologists from Serbia and Bulgaria has a long tradition. Individual scientific contacts, participation in scientific events, joint publications, and comparative studies are the most common forms of collaborative work. What has been done so far, however, does not meet the capabilities and interests of both parties and of sociologists in particular. The geographical proximity, the similarity of problems our societies are facing - demographic crisis, mass emigration, 'brain drain', poverty, growing social inequality,

\footnotetext{
1 anna.mantarova@abv.bg
} 
corruption, crime, lack of resources and capacity to respond quickly to emerging problems such as refugee crisis, difficulties for the sustainable development of our societies - are a prerequisite and an indicator for the need for joint efforts to establish a closer and more diverse forms of cooperation.

Taking the opportunity provided by the Editorial Board of Sociološki pregled / Sociological Review, we would like to make our colleagues from Serbia familiar with the works of contemporary Bulgarian sociologists. In order to give a broader view, three generations of authors have been selected - Academician Dimitar Dimitrov, a representative of the generation related to the institutionalization and the years of rapid development of Bulgarian sociology; already established sociologists of the middle generation - Professor, Doctor of Sociological Sciences Anna Mantarova, Professor, Doctor of Sociological Sciences Maya Kelian, Professor, Doctor of Political Science Georgi Manolov, Associate Professor Dr. Maria Zhelyazkova, Associate Professor Dr. Svetlana Stamenova; and young, but already prominent researchers - Associate Professor Dr. Petar Cholakov, Associate Professor Dr. Lyuba Spasova, Chief Assistant Dr. Todorka Kineva.

Apart from the generational aspect, the aim was to achieve thematic diversity by works treating variety of current and significant problems and processes - texts that study phenomena characteristic of Bulgarian society, as well as texts that study phenomena - of supranational nature, a consequence of global trends and processes.

The diversity of the works presented is enriched by the fact that some of them are mostly theoretical in nature, while others build their analyses on the basis of information from empirical research and statistics and give a detailed picture of social realities in today's Bulgarian society.

As once again I express my thanks for the opportunity to present ourselves before the Serbian sociological community, I hope that the proposed articles will help to get to know each other, will contribute to establishing new contacts and expand our cooperation. 
Бугарска академија наука,

Институт за филозофију и социологију

Софија (Бугарска)

\section{УДРУЖИВАЮЕ НАПОРА ПРЕД ЗАЈЕДНИЧКИМ ИЗАЗОВИМА \\ (Превоg In Extenso)}

Политичке промене у Бугарској крајем 80-их година 20. века означиле су почетак дубоких и свеобухватних реформи у бугарском друштву. Оне су имале значајан утицај на науку, а нарочито на социологију. Отвориле су се нове прилике, али су се појавили и озбиљни изазови.

Социологија је проширила своју позицију у обуци високообразованих стручњака и постала обавезан предмет у програму бројних високообразовних установа. Основан је велики број социолошких агенције које су се усредсредиле на испитивање јавног мњења у широком распону тема, стварајући на тај начин огромну количину емпиријског материјала који би се могао употребити за теоријска тумачења.

Када се Бугарска отворила према свету, стекли су се повољни услови за интеграцију бугарске социологије у водеће трендове. Она је добила своје трајно место у Европском истраживачком простору (ERA). Бугарски социолози већ две деценије раде на Оквиру и осталим програмима Европске комисије и осталих међународних институција и организација.

Међутим, бугарска социологија је истовремено доживела и много штете и потешкоћа. Истраживачке јединице са традицијом и неоспорним достигнућима затворене су или у знатној мери смањене. Због недовољних финансија, академска социологија суочила се са озбиљним изазовима. Потрага за неопходним новим средствима од спољних уговарача посредно је утицала на избор истраживачких тема. Исто тако је утицала и на примењене методе. Ипак, објашњење текућег сложеног и контрадикторног процеса трансформације у земљи предњачи међу свим проблемима и противречностима које су се појавили (Genov, 1998, str. 87). Упркос потешкоћама, бугарски социолози остварили су значајне резултате у истраживању и објашњавању нове друштвене стварности, при чему су и раније предлагали и наставили да предлажу начине за оптимизацију друштвеног развоја.

Сарадња између социолога из Србије и Бугарске има дугогодишњу традицију. Појединачни научни уговори, учешће на научним догађајима, заједничке публикације и упоредне студије најчешћи су облици те сарадње. Ипак, оно што је до сада постигнуто не задовољава капацитете и интересе обе стране, а нарочито социолога.

1 anna.mantarova@abv.bg 
Географска близина и слични проблеми са којима се суочавају наша друштва - демографска криза, масовна емиграција, одлив мозгова, сиромаштво, све већа друштвена неједнакост, корупција, криминал, недостатак средстава и могућности за брзо реаговање на новонастале проблеме као што је избегличка криза, потешкоће у одрживом развоју наших друштава - представљају предуслов и потребу за удруженим напорима како би се успоставили чвршћи и разноврснији облици сарадње.

Користећи прилику коју нам је пружила редакција Социолошкої йреїлеgа, желели бисмо да колеге из Србије упознамо са радовима савремених бугарских социолога. Да би се обезбедио шири увид, одабране су три генерације аутора - академик Димитар Димитров, представник генерације везане за институционализацију и године брзог развоја бугарске социологије; етаблирани социолози средње генерације - професор и доктор социолошких наука Ана Мантарова, професор и доктор социолошких наука Маја Келијан, професор и доктор политичких наука Георги Манолов, ванредни професор и доктор наука Марија Јелиашкова, ванредни професор и доктор Светлана Стаменова; као и млади, али већ еминентни истраживачи - ванредни професор и доктор наука Петар Чолаков, ванредни професор и доктор наука Љуба Спасова, и главни помоћник шефа катедре и доктор наука Тодорка Кинева.

Поред генерацијског аспекта, циљ је такође био остварити тематску разноликост укључивањем радова посвећених важним текућим проблемима и процесима онима који су карактеристични за бугарско друштво, као и онима супранационалне природе који су последица глобалних кретања и процеса.

Разноликост представљених радова додатно је обогаћена чињеницом да су неки од њих превасходно теоријске природе, док други граде анализе на основу података емпиријског истраживања и статистике и дају детаљну слику друштвене стварности у савременом бугарском друштву.

Изражавајући још једном захвалност због указане прилике да се представимо српској социолошкој заједници, надам се да ће предложени радови помоћи у међусобном упознавању, допринети успостављању нових веза и проширити нашу сарадњу.

\section{REFERENCES / ЛИTEPATУPA:}

Genov, N. (1998). Sociology. Sofia: Regional and Global Development. 